
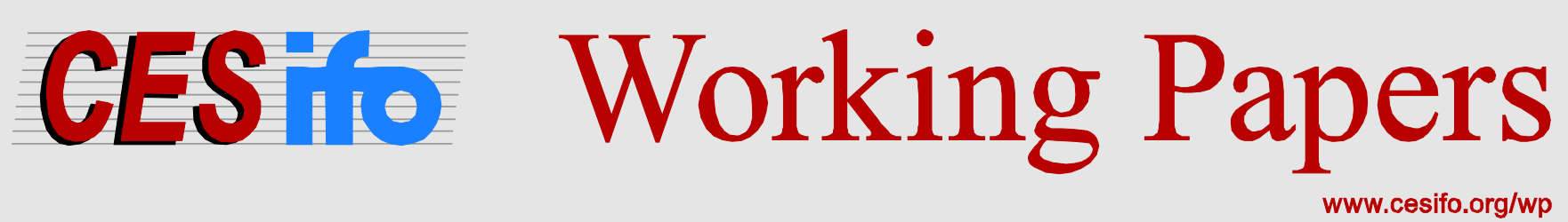

\title{
The Economics of Politics: Patronage and Political Selection in Italy
}

\author{
Federico Quaresima \\ Fabio Fiorillo
}

CESIFO WORKING PAPER NO. 6233

CATEGORY 1: PUBLIC FinANCE

DECEMBER 2016

\begin{abstract}
An electronic version of the paper may be downloaded
- from the SSRN website:

- from the RePEc website:

- from the CESifo website:

www.SSRN.com

www.RePEc.org

www.CESifo-group.org/wp
\end{abstract}




\title{
The Economics of Politics: Patronage and Political Selection in Italy
}

\begin{abstract}
This article investigates the patronage phenomenon in the italian, so called, Second Republic. In particular, the analysis argues that (ex) members of parliament are appointed to managerial boards in italian (partially) state-owned enterprises responding to political selection rationales. Indeed, direct political connections could be conceptualize as an instrument to control and reward politicians' loyalty throughout a legislature. Especially in a majoritarian electoral system, where the interests of political parties and districts may diverge, the formers would need patronage resource to assure themselves members of parliament loyalty when casting ballots. The results of the empirical investigation suggests that parliamentarians' loyalty does play a role in patronage appointments as well as the electoral result in the next electoral competition.
\end{abstract}

JEL-Codes: D720, D730.

Keywords: SOE, patronage, political selection, exit strategy.

Federico Quaresima

Università Politecnica delle Marche

Ancona / Italy

f.quaresima@pm.univpm.it
Fabio Fiorillo

Università Politecnica delle Marche

Ancona / Italy

f.fiorillo@univpm.it

September 19, 2016

We would like to thank Raffaella Santolini, Claudia Pigini and Matteo Picchio for their useful comments and suggestions. The Rodolfo de Benedetti foundation for the data set provision. Antonio Bubba for the assistance in the additional data collection. The views expressed are solely those of the authors. 


\section{Introduction}

Even though nowadays Italy is a well established democracy organized according the principles of free market and private property, the state retains an important role in several sectors of the economy ${ }^{2}$. The perceived success of the British Telecom initial public offering (1984) persuade many other industrialized countries to begin divesting State Owned Enterprises (SOEs). Italy has not been an exception: italian government, leaded by Silvio Berlusconi, launched a large privatization program in july 1994 (1. 474/1994).

It has been theoretically suggested by Sappington and Stiglitz (1987) that under conditions of perfect competition and without informational problems ownership should not matter. The original arguments in favor of public ownership were justified as a solution to the lack of the above conditions, and to market failures like externalities and natural monopolies. Actually, SOEs were created as a direct instrument to channel investments in priority sectors as perceived by the policy makers, to implement full employment policies and to promote a balanced regional development. Nevertheless, by the 1970s, the performance of SOEs came under increasing scrutiny due to inefficiency, mismanagement, corruption and political interference. Privatization of SOEs has been viewed as a policy instrument for reducing the impact of political factors on economic performance, as pointed out by Vickers and Yarrow (1991).

The dominant trend in literature advances political interference in SOEs operations as a negative influence on output targets ${ }^{3}$, as stated among others by Boubakri et al. (2008), Menozzi et al. (2012) and Carretta et al. (2012) Also, there is a consensus about how government ownership is an effective channel of redistribution for political dividends. SOEs would tend to answer to political masters instead of market rationales as pointed out by Clarke and Cull (2002), Cragg and Dyck (2003) and Boubakri et al. (2011). Indeed, politicians forfeit an important means of generating political support when they privatize SOEs, losing the possibility to provide public employment and/or lucrative contracts to their supporters, like remarked by Shleifer and Vishny (1994). Many authors have criticized the italian way of privatizing state-owned enterprises (SOEs) ${ }^{4}$. Notwithstanding the privatization process that took place since the 1990s, the public sector continues to own large shares in many utilities such as gas and water supply, rail transport, airlines and so forth. We assume that this enduring role of the state in SOEs and partially privatized firms could be an instrument for the resource patronage ${ }^{5}$. Furthemore, also local government units (LGUs) have freedom of choice about the ownership structure of firms providing local public services. In Italy, as well as in other European countries, LGUs can autonomously organize local utilities: the formers can be the sole owners of the latters, or they can stand in co-participation with other LGUs or with private

\footnotetext{
${ }^{2}$ See, among others, Bortolotti and Faccio (2009)

${ }^{3}$ Moreover, Chaney et al. (2011) show how politically connected firms disclose lower quality accounting information.

${ }^{4}$ Among others Cavaliere (1997), Macchiati (1999) and De Nardis (2000).

${ }^{5}$ See Di Mascio (2011).
} 
agents. Bortolotti et alia (2007) use the term "municipal capitalism" to describe the phenomenon. Including local public utilities in the firms possibly used for patronage should be correct, at least for the italian case. Despite italian parties show a low level of verticalization between national and sub-national units, "the central office controls the organizational regulation of the sub-national level, the selection of candidates to national elections and the allocation of state funds." 6 In addition, especially in Italy, the legal definitions of the public enterprises are variable: some has mixed ownership (public-private), some are totally private but under the supervision of public sector entities and pure SOEs are totally public (enti pubblici). This organizational intricacy dampers the public sector accountability and probably favors the intertwining of (partially) public firms and patronage dynamics. In Italy, in the period under analysis (1994-2003), government alternation could have played a role in SOEs politicization through the substitution of directors elected by the previous governing party. ${ }^{7}$

With this research we want to empirically test patronage occurrences and verify if governing parties exploit appointments in SOEs boards of director as a means of control and reward for their loyal members of parliament (MPs), as suggested by Bolleyer (2009) and by Kopecký et alia (2012). In this perspective patronage represents a useful resource for the party self-maintenance: a selective benefit to assure individual loyalty. A patron (government party) controls a desired good (appointment) and has the choice to reward certain MPs and exclude others. Hence, the MP provides support hoping for the appointment or, vice versa, the government party selects the MPs' appointments in the expectation that support (or loyalty) will be provided in the future. The above dynamic would figure an agency relationship between political parties and MPs, where the formers exploit the selective incentives represented by an appointment to a SOE board of director, thanks to their persistent control on SOEs (and partially privatized firms), and the latters may reserve a chance for a political career, as intended by Mattozzi and Merlo (2008). ${ }^{8}$ Parties usually offer incentives to MPs for voting along party lines ${ }^{9}$. However elected MPs are accountable to their constituents and they can be tempted to cultivate a personal vote. ${ }^{10}$ The existence of singlemember districts represents a clear link between a geographically defined group of voters and the MP (Mitchell 2000, Grofman 2005). Moreover, given the reduction in party attachments constituents may be more willing to consider MP behaviour when casting their votes ${ }^{11}$. Then, viewing patronage as an organizational resource for parties, we propose SOE boards appointments as additional tools to stimulate MPs loyalty in roll-call votes as in Kopecký et al. (2012). We focus our attention on three cohorts of MPs: those elected to the XII, XIII and

\footnotetext{
${ }^{6}$ Ignazi and Pizzimenti (2014).

${ }^{7}$ As supposed by Di Mascio (2011).

${ }^{8}$ See on this Ennser-Jedenastik (2014).

${ }^{9}$ Parties can punish rebellion through several mechanisms. See for this Bowler et alia (1999), Kam (2009) and Milligan and Rekkas (2008), among others.

${ }^{10}$ See the seminal work of Cain, Ferejohn and Fiorina (1987) and Carson et al. (2010. For the italian case see Golden (2003).

${ }^{11}$ See on this, among others, Zittel and Gschwend (2008), Kam (2009), Bellucci and Segatti (2010) and Vivyan and Wagner (2012).
} 
Figure 1: Motivations for patronage

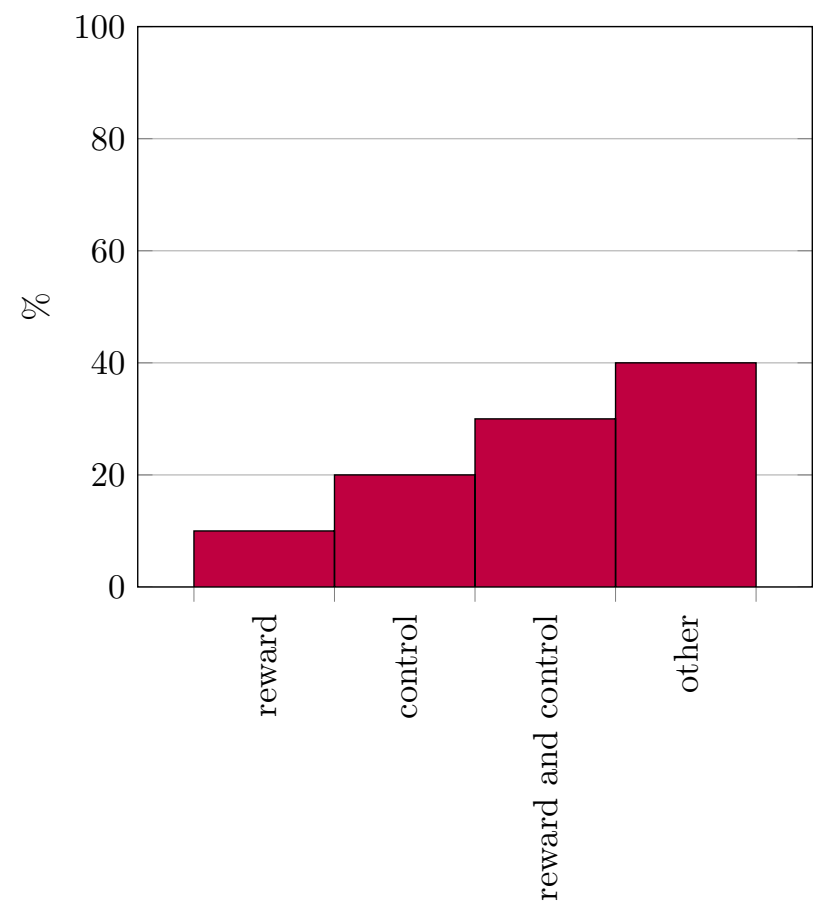

Source: Di Mascio (2012).

XIV legislatures of italian parliament. By doing this we avoid structural break due to the change in the italian electoral rule. The so-called Legge Mattarella ${ }^{12}$ established that a $75 \%$ of the representatives were elected with a majoritarian system and the remaining $25 \%$ according to a proportional system (mixed system). Italy was divided into 475 uninominal House districts. In each district, one MP was elected by simple plurality according to a pure first-past-the-post election. The remaining representatives were then selected with a proportional rule among the candidates of the parties that reached a treshold of at least the $4 \%$ of the total national votes, with a mechanism favoring the losing parties in the uninominal districts. For the Senate, 232 MPs were elected according to a simple plurality rule in uninominal districts and the remaining senators were selected according to a proportional system.

The rest of the paper is organised as follows: in the next two sections we describe the dataset and the methodology used to conduct our empirical investigation; in Section 4 we present the results of our empirical analysis; finally concluding remarks are provided in Section 5.

\footnotetext{
${ }^{12}$ From the legislator Sergio Mattarella who sponsored the electoral rule reform.
} 


\section{Data and variables}

The dataset used is the Italian Members of Parliament (2009) dataset, kindly provided by the Rodolfo De Benedetti foundation. These data contain detailed information on all individuals who have been elected to the Italian Parliament, since the inception of the Italian Republic in 1948. The data span 60 years (1948-2008). In addition we manually compiled another dataset regarding the appointments of MPs in SOEs boards of directors thanks to the Telemaco online archive of the Chamber of Commerce of Italy. Thanks to this database we have been able to investigate MPs' past and present experience as members (or presidents) of boards of directors in publicly owned firms ${ }^{13}$

The empirical analysis is conducted on a sample of 1237 italian MPs elected over the period 1994-2001 ${ }^{14}$. Among these $1237 \mathrm{MPs}, 808$ are present in only one legislature, 298 in two legislatures (not necessarily consecutive) and 131 in every included legislature. Totally we have 1797 observations.

Our dependent variable is appointment: it is a dichotomous variable equal to one if, after the end of the legislature and within two years, the MP has been appointed in a $\mathrm{SOE}^{15}$ board of director, zero otherwise. We chose a period of two years to consider the organizational time that may be required to a party to make the appointment effective. In Italy the power of parties in appointing (ex) politicians in publicly owned firms boards has been underlined by Di Mascio (2011), who explicitly defines resource patronage the control of these appointments as a usage of public resources subsequently used as selective incentives.

Several regressors are included among our political key variables. The first one, rebellion rate, is a proxy of the dissent MP expresses towards his own party. It is a ratio between the number or votes for which MP was not present without a justification and the total number of votes at which MP should have been present $^{16}$

We consider prominent also the electoral result of MPs in the following national election, in order to test if the appointment could be exploited as an exit strategy by the MP. The (in sample) MPs' feasible outcomes are three: at the end of a term he/she can run and win (and so be reelected), run and loose, or retire. The first case is adopted as base case and two dummy variables have been put into the regression equation for the rest of the possible electoral results (defeat and retire). In addition we test if a MP's parliamentary group change, during the legislature in examination, may be correlated to the likelihood of being appointed including a dummy variable (changegroup) equal to one if the MP

\footnotetext{
${ }^{13}$ Where a public entity holds, directly and indirectly, firm capital shares.

${ }^{14}$ XII, XIII and XIV state legislature. Observations with missing values are dropped from the sample

${ }^{15}$ We consider SOEs firms directly or indirectly owned by the State or by LGUs.

${ }^{16}$ We counted absences without justification as passive nay votes similarly to Heller and Mershon (2008). We have considered this kind of dissent appropriate to let the variable indicate a MP's signal to her/his own party. ${ }^{17}$ Alternatively rebellion rate could be considered a proxy of MPs shrinking or rent seeking. Under this alternative view parties could consider an appointment as a reward for the MP's effort in parliament and not for his/her loyalty. See on this Gagliarducci et al.(2010).
} 
switched parliamentary group during the term. The inclusion of this regressor try to capture a possible reward (the appointment) following a party switching. Including this regressor is justified by the fact that italian parliamentary groups long evinced substantial stability in membership. From the First Legislature (1948-1953) through the Ninth (1983-1987) the number of individual desertions from groups has been very low as maintained by Verzichelli (1996). The Tenth Legislature (1987-1992) witnessed multiple switches but these involved MPs moving in clusters, not individually. Verzichelli (1999) reports that even during the Eleventh Legislature (1992-1994) switches have been rare and thereupon the 1994 elections, for the first time, MPs began moving as individuals rather than in groups, and switching became widespread ${ }^{18}$. Then considering patronage appointments as selective individual reward could be in line with the individual switches from the Twelfth legislature onwards.

The variable opposition is included to discriminate between ruling parties and opposition ones. Considering that the appointments occurred next the end of each legislature and the strict alternation in government in the sample period, a positive value of the opposition variable would suggest a kind of spoils system in the "market of appointments" 19 . Once in power, the ex opposition party would allocate its loyal (ex) MPs to the SOEs boards. In addition, we think that the political expertise could affect positively the likelihood of being appointed in a SOE board after serving in parliament. The variable exp. lex account for the MP's political experience, measured in number of national parliament legislatures in which the MP has been present before being elected in the legislature under investigation.

Since 1982, the Italian law requires MPs to disclose their annual tax returns ${ }^{20}$. Then among included control regressors we can insert extra income 1st year which is a continous variable reporting the annual income from activities outside parliament, expressed in 2005 thousands of euros, in the first year of the term. Being unavailable the MPs income before entering the Parliament we use this income variable as a proxy the MP's income before entering the parliament $^{21}$, and, as in Galasso and Nannicini (2011), as a proxy for the MP's ability. In addition we include the age variable which specifies the age a MP had at the end of the legislature, in order to check if the MP's age has a valuable effect on being appointed.

In addition, public exp. and private exp. are two dummy variables equal to one if the MP, respectively, have had an appointment in a SOE board of directors before entering the parliament and if he worked as manager of a (or was a self employed) private firm. This qualitative variables, in our view, should represent a MP bent in leading a (public) firm and his talent. If this control would be significant and positive we could add a professional motivation for the ap-

\footnotetext{
${ }^{18}$ See also Heller and Mershon (2005).

${ }^{19}$ Being the opposition parties the ruling parties in the next term.

${ }^{20}$ Law 441 of July, 1982 .

${ }^{21}$ We think that the income value of the first year of the term should be the best proxy for the income gained before entering parliament because of the declining path of this variable during the legislatures years.
} 
pointment. Legislatures dummy variables $\left({ }_{-}\right.$III lex and $\_I V$ lex $)$ and female are included in the regression capturing, respectively, possible time trends and gender issues.

\section{The econometric model}

In this section we illustrate the empirical model of our work. A first analysis will consider a linear probability model. Next we will show how a nonlinear model confirms the main results. Nonlinearity is considered more appropriate given the large fraction of negative predicted values by ordinary least squares estimation.

The goal of the research is to investigate how MPs' political characteristics could influence the probability of being appointed in a SOE board of directors after a term in parliament. We implement the following regression starting from a pooled ordinary least squares estimation.

$$
p\left(y=1 \mid X_{i}\right)=\alpha+\beta X_{i}+\text { lex }+ \text { female }+\epsilon_{i}
$$

Table 1: Descriptive statistics

\begin{tabular}{lccccc}
\hline Variable & Obs & Mean & Std. Dev. & Min & Max \\
\hline appointment & 1797 & 0.0550918 & 0.2282229 & 0 & 1 \\
rebellion rate & 1797 & 0.3183297 & 0.2125934 & 0.001 & 0.994 \\
defeat & 1797 & 0.1880913 & 0.3908938 & 0 & 1 \\
retire & 1797 & 0.2598776 & 0.4386893 & 0 & 1 \\
changegroup & 1797 & 0.2771285 & 0.4477051 & 0 & 1 \\
opposition & 1797 & 0.4607679 & 0.4985972 & 0 & 1 \\
exp. lex & 1797 & 1.905954 & 1.388207 & 0 & 11 \\
extra income 1st year & 1797 & 85.27431 & 367.3043 & -9.737 & 11515.28 \\
age & 1797 & 52.39455 & 9.839844 & 29 & 86 \\
private exp. & 1797 & 0.1346689 & 0.3414646 & 0 & 1 \\
public exp. & 1797 & 0.0467446 & 0.21115 & 0 & 1 \\
education & 1797 & 16.35893 & 2.569468 & 8 & 18 \\
female & 1797 & 0.1235392 & 0.3291467 & 0 & 1 \\
\hline
\end{tabular}

Notwithstanding the dataset is strongly unbalanced we tried to exploit the panel form of the dataset, even if 808 MPs out of 1237 are present only once in the sample. In line with Wooldridge (2010) we test whether fixed effects are present by using a Hausman test, checking whether there is a statistically significant difference between the fixed effect estimator and the random effect estimator. Using micro data, and allowing for heteroskedasticity and autocorrelation, we conduct two versions of a robust Hausman test. In the first one, proposed 
by Wooldridge (2002), a random effects equation is estimated with additional variables, consisting of the original covariates transformed into deviations from their means (for time-varying regressors), using panel-robust standard errors. The test statistic is a Wald test of the significance of these additional regressors. Obtaining a p-value of 0.0986 the additional regressors are not significant at the standard 5\% level. Being the obtained p-value not so conclusive we implement another type of cluster-robust Hausman test based on bootstrapping, following Cameron and Trivedi (2005). The covariance matrix is estimated by bootstrap resampling over $i d^{22}$. Using 5000 bootstrap repetitions the p-value of the test converges to 0.1512 suggesting the non significance of individual fixed effects. In absence of fixed effects we implement a random effect estimation, which tend to be fully efficient under the RE model.

Moving to nonlinearity to emend negative predicted outcomes by the linear probability model (for about $22 \%$ of the sample) we also implement a pooled probit regression. Therefore, in line with the preceding analysis in the linear case, we test for the presence of fixed effects through a Hausman test for non linear models ${ }^{23}$, in line with Mundlak (1978). We run an auxiliary regression including as additional explanatory variables the individual means of all the time-varying covariates and then we run the model as a random effect probit. Then we test the significance of the individual means trough a Wald test. Assuming fixed effects follow a normal distribution and being linear combinations of the individual means times related coefficients, also in this non linear version of the model we can exclude fixed effects. In this case the p-value is 0.9955 . Moreover, we can notice a nearly zero value of the variance due to differences across panels (intraclass correlation).

As an alternative way to establish how negligible should be a panel analysis, given the characteristics of our sample, in Tables 4-5 we propose other two estimates (for linear and non linear specifications) including in the sample only those MPs elected just once in the sample period. The difference in coefficients between the subsample estimates and the full sample ones should suggest us the importance of the within variances in explaining the phenomenon.

Then we calculate the average marginal effects to make the linear and non linear estimates comparable. We provide, in addition, also the average marginal effects related to the corresponding logit model to see how imposing different distributional assumptions on the error term of the latent regression could modify the estimates.

Finally we test the exogeneity of the retire variable through an instrumental variable approach using the $a g e^{24}$ variable as an instrument in the linear specification. We conduct the Hausman test for endogeneity ${ }^{25}$ through an auxiliary regression. For the other variables included in the estimation we have not available instruments to check endogeneity issues.

\footnotetext{
${ }^{22}$ Our identification variable.

${ }^{23}$ See Wooldridge (2010)

${ }^{24}$ After excluding this variable from the main regression equation.

${ }^{25}$ See on this Wooldridge (2010) among others.
} 


\section{Results}

Once we exclude the possibility for fixed effects through the two heterogeneityautocorrelation robust Hausman tests implemented (for the linear specification) and through a Mundlak approach (for the non linear specification), we prefer the pooled analysis respect to a random effects model also considering that the coefficients and the significance of the variables of main interest remains (even if at a lower significance level) once the estimation is based on a subsample in which MPs compare only once, excluding in this way within heterogeneity ${ }^{26}$. Determining the "correct" specification of the model is not necessarily an issue in the present work. The specific form of the function that maps the index model into the response probability (the identity function for the LPM, the standard normal or the standard logistic cumulative distribution functions for the probit model and the logit model, respectively) can not be derived from an existing economic model. Moreover, given that the main purpose of our study is to approximate partial and marginal effects averaged across the distribution of the included (political) regressors, most likely LPM should do a nice job ${ }^{27}$, even if nothing guarantee that LPM provides good estimates of the partial effects for extreme values of the included continuous regressors. In table 6 we report comparable values, the parameters estimates of LPM and the average partial and marginal effects of the probit and the logit model. We assume that the differences in the estimates are not so huge to question the general sense of the results.

The results of the estimation of the econometric models, illustrated in Tables $2-3$, show that, beyond the specification of the model some covariates are always statistically significant in explaining this particular labor market of italian MPs. In both specifications, linear and non linear, political variables as the electoral result in the next elections and the MP's rate of rebellion to his own party in the legislature are strongly significant. The related signs of the coefficients seem to indicate appointments in SOEs boards as a patronage exit strategy for MPs who have been loyal to party in the previous legislature ${ }^{28}$. The opposition regressor, being positive, tends to confirm what is general known as the spoils system. Given that in each legislature in the sample the opposition party become the ruling one after the next elections, and that the appointments are made after the vote, we can maintain that, once in power, the ex opposition party nominates its (ex) MPs in the boards of directors of partially privatized firms, still in control of parties. As regards the control variables the estimation of the model shows that both education and female have a negative effect, although negligible, on being appointed after the term. These findings seem to suggest

\footnotetext{
${ }^{26}$ In addition, especially in the non liner case, the fraction of variance due to individual unobserved effect is very close to zero, so that the possible gain in exploiting the data set panel form here results rather useless, at the cost of the assumptions about the error term. This could be the result of having a strong unbalanced panel data set, with about the half of the sample having only one observation.

${ }^{27}$ See Wooldridge (2010). For an alternative view of the issue see Horace and Oaxaca (2006).

${ }^{28}$ Alternatively, viewing rebellion rate as a measure of shrinking, the appointment could be thought as a reward to a low absence rate in parliament.
} 
firstly, that more educated MPs are less interested in an exit strategy at the end of their career as politicians and secondly, that also in this particular labor market we assist to a gender issue ${ }^{29}$. Lastly, we test the endogeneity of the retire variable using as instrument the age variable. Implementing the Hausman procedure and employing the usual t-test on the computed residuals of the first stage regression, we obtain that they are statistical insignificant, with a p-value equal to 0.869 . This result suggests us the exogeneity of the retire variable.

\section{Concluding remarks}

Differently from the so-called "revolving door" mechanism, where politicians take up consulting or lobbying jobs in the private market after exiting office, the patronage phenomenon, as Kopecký and Scherlis (2008) define it, is "the power of a party to appoint people to positions in public and semi-public life". The established main motivations for patronage are reward and control as in Kopecký et alia (2012): "the former implies that parties hand out appointments to fellow partisans in return for their loyalty, whereas the latter suggests that parties intend to exert influence over some areas of public policy". Our empirical analysis try to shed light on a particular, and limited, segment of this phenomenon in Italy, considering MPs as the targets of appointments in partially privatized firms by political parties. In doing this we assume that, as stated by Di Mascio (2012), parties can effectively control public and semi-public firms, being themselves the substantial appointing authority for this particular kind of enterprises. In addition, we fully realize that MPs could represent only a very restricted fraction of the possible targets of the patronage appointments made in the political environment (possibly being only the tip of the iceberg, the most visible part of the phenomenon).

Our results show how parties exploit political appointments in managerial board of controlled firms as an individual disciplining tool for the loyalty shown by its MPs during a (previous) legislature. Considering how the literature, even specifically for the italian case, describes party loyalty as a burden for MPs' reelection concerns, we suggest how a political appointment in a semi-public firm could be used by parties as a reward, or a possible exit strategy, for loyal parliamentarians.

Our work provides some evidence of the quantitative dimension of the phenomenon. In our view the analysis could represent a starting point in a possible debate about MPs conflict of interests (and not only about members of Government, as the recent reform process has intended ${ }^{30}$ ). A future research project could be to implement a similar analysis concerning legislatures ruled by the new proportional electoral rule, as modified by l. 270/2005.

\footnotetext{
${ }^{29}$ The education significance holds in every estimated model. The female significance hold only in the LPM.

${ }^{30}$ We refer to l. $190 / 2012$ and to d.lgs. 39/2013.
} 
Table 2: Linear models comparison

\begin{tabular}{|c|c|c|}
\hline appointment & Pooled OLS & RE estimator \\
\hline rebellion rate & $\begin{array}{c}-0.0940^{* * *} \\
(-3.64)\end{array}$ & $\begin{array}{c}-0.0737^{* *} \\
(-2.63)\end{array}$ \\
\hline defeat & $\begin{array}{c}0.122^{* * *} \\
\quad(6.62)\end{array}$ & $\begin{array}{c}0.129 * * * \\
\quad(6.60)\end{array}$ \\
\hline retire & $\begin{array}{c}0.0994^{* * *} \\
\quad(6.68)\end{array}$ & $\begin{array}{c}0.103^{* * *} \\
(6.50)\end{array}$ \\
\hline changegroup & $\begin{array}{c}0.0148 \\
(1.14)\end{array}$ & $\begin{array}{c}0.00784 \\
(0.66)\end{array}$ \\
\hline opposition & $\begin{array}{c}0.0387^{* * *} \\
\quad(3.31)\end{array}$ & $\begin{array}{c}0.0331^{* *} \\
(2.97)\end{array}$ \\
\hline extra income 1st year & $\begin{array}{c}0.000005 \\
(1.15)\end{array}$ & $\begin{array}{c}0.000002 \\
(0.38)\end{array}$ \\
\hline age & $\begin{array}{c}-0.000006 \\
(-0.01)\end{array}$ & $\begin{array}{c}0.00002 \\
(0.03)\end{array}$ \\
\hline private exp. & $\begin{array}{l}0.0168 \\
(0.95)\end{array}$ & $\begin{array}{l}0.0148 \\
(0.78)\end{array}$ \\
\hline public exp. & $\begin{array}{c}0.0125 \\
(0.43)\end{array}$ & $\begin{array}{l}0.0127 \\
(0.42)\end{array}$ \\
\hline education & $\begin{array}{c}-0.00459^{*} \\
(-1.99)\end{array}$ & $\begin{array}{c}-0.00597^{*} \\
(-2.28)\end{array}$ \\
\hline XIII lex & $\begin{array}{c}0.00568 \\
(0.48)\end{array}$ & $\begin{array}{c}-0.000414 \\
(-0.04)\end{array}$ \\
\hline XIV lex & $\begin{array}{c}0.0311^{*} \\
(2.21)\end{array}$ & $\begin{array}{c}0.0308^{*} \\
(2.27)\end{array}$ \\
\hline female & $\begin{array}{c}-0.0288^{*} \\
(-2.14)\end{array}$ & $\begin{array}{c}-0.0305^{*} \\
(-2.07)\end{array}$ \\
\hline constant & $\begin{array}{c}0.0781 \\
(1.62)\end{array}$ & $\begin{array}{c}0.0965 \\
(1.76)\end{array}$ \\
\hline $\begin{array}{l}N \\
R^{2}\end{array}$ & $\begin{array}{l}1797 \\
0.079\end{array}$ & 1797 \\
\hline $\begin{array}{l}\text { sigma_u } \\
\text { sigma_e } \\
\text { rho }\end{array}$ & & $\begin{array}{l}0.1607 \\
0.1741 \\
0.4600\end{array}$ \\
\hline
\end{tabular}


Table 3: Non linear models comparison

\begin{tabular}{|c|c|c|}
\hline appointment & Pooled Probit & Random effects Probit \\
\hline rebellion rate & $\begin{array}{c}-1.241^{* *} \\
(-2.84)\end{array}$ & $\begin{array}{l}-1.241 \\
(-0.78)\end{array}$ \\
\hline defeat & $\begin{array}{c}1.387^{* * *} \\
(7.70)\end{array}$ & $\begin{array}{l}1.387 \\
(0.83)\end{array}$ \\
\hline retire & $\begin{array}{c}1.285^{* * *} \\
(7.17)\end{array}$ & $\begin{array}{l}1.285 \\
(0.84)\end{array}$ \\
\hline changegroup & $\begin{array}{l}0.191 \\
(1.55)\end{array}$ & $\begin{array}{l}0.191 \\
(0.71)\end{array}$ \\
\hline opposition & $\begin{array}{c}0.372^{* *} \\
(2.87)\end{array}$ & $\begin{array}{l}0.372 \\
(0.79)\end{array}$ \\
\hline extra income 1st year & $\begin{array}{c}-0.00001 \\
(-0.04)\end{array}$ & $\begin{array}{c}-0.00001 \\
(-0.04)\end{array}$ \\
\hline age & $\begin{array}{c}-0.00166 \\
(-0.26)\end{array}$ & $\begin{array}{c}-0.00166 \\
(-0.25)\end{array}$ \\
\hline private exp. & $\begin{array}{l}0.155 \\
(1.06)\end{array}$ & $\begin{array}{l}0.155 \\
(0.73)\end{array}$ \\
\hline public exp. & $\begin{array}{l}0.156 \\
(0.68)\end{array}$ & $\begin{array}{l}0.156 \\
(0.61)\end{array}$ \\
\hline education & $\begin{array}{c}-0.0376^{*} \\
(-2.06)\end{array}$ & $\begin{array}{c}-0.0376 \\
(-0.74)\end{array}$ \\
\hline XIII lex & $\begin{array}{c}0.0573 \\
(0.39)\end{array}$ & $\begin{array}{c}0.0573 \\
(0.39)\end{array}$ \\
\hline _XIV lex & $\begin{array}{l}0.273 \\
(1.87)\end{array}$ & $\begin{array}{l}0.273 \\
(0.76)\end{array}$ \\
\hline female & $\begin{array}{l}-0.372 \\
(-1.88)\end{array}$ & $\begin{array}{l}-0.372 \\
(-0.79)\end{array}$ \\
\hline constant & $\begin{array}{c}-1.824^{* * *} \\
(-3.84)\end{array}$ & $\begin{array}{l}-1.824 \\
(-0.86)\end{array}$ \\
\hline $\begin{array}{l}N \\
R^{2} a d j\end{array}$ & $\begin{array}{c}1797 \\
0.2021\end{array}$ & 1797 \\
\hline Logpseudolikelihood & -305.76247 & -305.76253 \\
\hline $\begin{array}{l}\text { Wald } \chi^{2}(13) \\
\ln \left(\sigma_{v}^{2}\right)\end{array}$ & 85.94 & $\begin{array}{c}99.49 \\
-9.0345\end{array}$ \\
\hline$\sigma_{v}$ & & 0.1092 \\
\hline$\rho$ & & 0.0001 \\
\hline
\end{tabular}


Table 4: OLS sample comparison

\begin{tabular}{|c|c|c|}
\hline appointment & Full sample & Sub sample \\
\hline rebellion rate & $\begin{array}{c}-0.0940^{* * *} \\
(-3.64)\end{array}$ & $\begin{array}{c}-0.137^{*} \\
(-2.37)\end{array}$ \\
\hline defeat & $\begin{array}{c}0.122^{* * *} \\
(6.62)\end{array}$ & $\begin{array}{c}0.108^{* * *} \\
(4.04)\end{array}$ \\
\hline retire & $\begin{array}{c}0.0994^{* * *} \\
(6.68)\end{array}$ & $\begin{array}{c}0.0873^{* * *} \\
(3.33)\end{array}$ \\
\hline changegroup & $\begin{array}{c}0.0148 \\
(1.14)\end{array}$ & $\begin{array}{c}0.0334 \\
(1.44)\end{array}$ \\
\hline opposition & $\begin{array}{c}0.0387^{* * * *} \\
(3.31)\end{array}$ & $\begin{array}{c}0.0518^{*} \\
(2.37)\end{array}$ \\
\hline extra income 1 st year & $\begin{array}{c}0.000005 \\
\quad(1.15)\end{array}$ & $\begin{array}{c}0.0000506 \\
(0.90)\end{array}$ \\
\hline age & $\begin{array}{c}-0.000006 \\
(-0.01)\end{array}$ & $\begin{array}{c}-0.000362 \\
(-0.37)\end{array}$ \\
\hline private exp. & $\begin{array}{c}0.0168 \\
(0.95)\end{array}$ & $\begin{array}{c}0.00543 \\
(0.18)\end{array}$ \\
\hline public exp. & $\begin{array}{c}0.0125 \\
(0.43)\end{array}$ & $\begin{array}{c}0.00374 \\
(0.10)\end{array}$ \\
\hline education & $\begin{array}{c}-0.00459^{*} \\
(-1.99)\end{array}$ & $\begin{array}{c}-0.00995^{*} \\
(-2.43)\end{array}$ \\
\hline XIII lex & $\begin{array}{c}0.00568 \\
(0.48)\end{array}$ & $\begin{array}{c}0.00988 \\
(0.38)\end{array}$ \\
\hline XIV lex & $\begin{array}{c}0.0311^{*} \\
(2.21)\end{array}$ & $\begin{array}{c}0.0232 \\
(0.87)\end{array}$ \\
\hline female & $\begin{array}{c}-0.0288^{*} \\
(-2.14)\end{array}$ & $\begin{array}{c}-0.0346 \\
(-1.44)\end{array}$ \\
\hline constant & $\begin{array}{c}0.0781 \\
(1.62)\end{array}$ & $\begin{array}{c}0.190^{*} \\
(2.10)\end{array}$ \\
\hline $\begin{array}{l}N \\
R^{2}\end{array}$ & $\begin{array}{c}1797 \\
0.079\end{array}$ & $\begin{array}{c}808 \\
0.0515\end{array}$ \\
\hline
\end{tabular}


Table 5: Probit sub sample comparison

\begin{tabular}{|c|c|c|}
\hline appointment & Full sample & Sub sample \\
\hline rebellion rate & $\begin{array}{c}-1.241^{* *} \\
(-2.84)\end{array}$ & $\begin{array}{c}-1.042^{*} \\
(-1.97)\end{array}$ \\
\hline defeat & $\begin{array}{c}1.387^{* * *} \\
(7.70)\end{array}$ & $\begin{array}{c}0.909 * * * \\
(3.77)\end{array}$ \\
\hline retire & $\begin{array}{c}1.285^{* * *} \\
(7.17)\end{array}$ & $\begin{array}{c}0.808^{* *} \\
(3.15)\end{array}$ \\
\hline changegroup & $\begin{array}{l}0.191 \\
(1.55)\end{array}$ & $\begin{array}{c}0.257 \\
(1.69)\end{array}$ \\
\hline opposition & $\begin{array}{c}0.372^{* *} \\
(2.87)\end{array}$ & $\begin{array}{c}0.343^{*} \\
(2.23)\end{array}$ \\
\hline extra income 1st year & $\begin{array}{c}-0.00001 \\
(-0.04)\end{array}$ & $\begin{array}{c}0.000256 \\
(0.71)\end{array}$ \\
\hline age & $\begin{array}{c}-0.00166 \\
(-0.26)\end{array}$ & $\begin{array}{c}-0.00410 \\
(-0.51)\end{array}$ \\
\hline private exp. & $\begin{array}{l}0.155 \\
(1.06)\end{array}$ & $\begin{array}{c}0.0581 \\
(0.30)\end{array}$ \\
\hline public exp. & $\begin{array}{l}0.156 \\
(0.68)\end{array}$ & $\begin{array}{c}0.0742 \\
(0.28)\end{array}$ \\
\hline education & $\begin{array}{c}-0.0376^{*} \\
(-2.06)\end{array}$ & $\begin{array}{c}-0.0584^{* *} \\
(-2.69)\end{array}$ \\
\hline XIII lex & $\begin{array}{c}0.0573 \\
(0.39)\end{array}$ & $\begin{array}{c}0.0439 \\
(0.25)\end{array}$ \\
\hline _XIV lex & $\begin{array}{l}0.273 \\
(1.87)\end{array}$ & $\begin{array}{l}0.122 \\
(0.66)\end{array}$ \\
\hline female & $\begin{array}{l}-0.372 \\
(-1.88)\end{array}$ & $\begin{array}{l}-0.346 \\
(-1.35)\end{array}$ \\
\hline constant & $\begin{array}{c}-1.824^{* * *} \\
(-3.84)\end{array}$ & $\begin{array}{l}-0.942 \\
(-1.59)\end{array}$ \\
\hline $\begin{array}{l}N \\
R^{2} a d j .\end{array}$ & $\begin{array}{c}1797 \\
0.2021\end{array}$ & $\begin{array}{c}808 \\
0.0975\end{array}$ \\
\hline
\end{tabular}

$t$ statistics in parentheses

$* p<0.05,{ }^{* *} p<0.01,{ }^{* * *} p<0.001$ 
Table 6: Pooled models. Average effects comparison.

\begin{tabular}{|c|c|c|c|}
\hline appointment & LPM & PROBIT & LOGIT \\
\hline rebellion rate & $\begin{array}{c}-0.101^{* * *} \\
(-3.85)\end{array}$ & $\begin{array}{c}-0.118^{* *} \\
(-3.16)\end{array}$ & $\begin{array}{c}-0.134^{* * * *} \\
(-3.52)\end{array}$ \\
\hline defeat & $\begin{array}{c}0.124^{* * * *} \\
\quad(6.67)\end{array}$ & $\begin{array}{c}0.129^{* * * *} \\
(7.59)\end{array}$ & $\begin{array}{c}0.146^{* * *} \\
(6.75)\end{array}$ \\
\hline retire & $\begin{array}{c}0.101^{* * * *} \\
\quad(6.72)\end{array}$ & $\begin{array}{c}0.118^{* * * *} \\
(7.11)\end{array}$ & $\begin{array}{c}0.136^{* * * *} \\
(6.39)\end{array}$ \\
\hline changegroup & $\begin{array}{c}0.0156 \\
(1.20)\end{array}$ & $\begin{array}{c}0.0182 \\
(1.60)\end{array}$ & $\begin{array}{c}0.0189 \\
(1.63)\end{array}$ \\
\hline opposition & $\begin{array}{c}0.0387 * * * \\
(3.31)\end{array}$ & $\begin{array}{c}0.0340^{* *} \\
(2.95)\end{array}$ & $\begin{array}{c}0.0375^{* *} \\
(3.29)\end{array}$ \\
\hline exp. lex & $\begin{array}{c}0.00495 \\
(1.50)\end{array}$ & $\begin{array}{c}0.00479 \\
(1.14)\end{array}$ & $\begin{array}{c}0.00398 \\
(0.96)\end{array}$ \\
\hline extra income 1st year & $\begin{array}{c}0.00000717 \\
(1.50)\end{array}$ & $\begin{array}{c}0.00000211 \\
(0.12)\end{array}$ & $\begin{array}{c}0.00000739 \\
(0.44)\end{array}$ \\
\hline age & $\begin{array}{c}-0.000229 \\
(-0.38)\end{array}$ & $\begin{array}{c}-0.000296 \\
(-0.51)\end{array}$ & $\begin{array}{c}-0.000417 \\
(-0.68)\end{array}$ \\
\hline private exp. & $\begin{array}{c}0.0166 \\
(0.94)\end{array}$ & $\begin{array}{c}0.0136 \\
(1.03)\end{array}$ & $\begin{array}{c}0.0140 \\
(1.07)\end{array}$ \\
\hline public exp. & $\begin{array}{c}0.0165 \\
(0.56)\end{array}$ & $\begin{array}{c}0.0179 \\
(0.83)\end{array}$ & $\begin{array}{c}0.0167 \\
(0.79)\end{array}$ \\
\hline education & $\begin{array}{c}-0.00462^{*} \\
(-2.00)\end{array}$ & $\begin{array}{c}-0.00353^{*} \\
(-2.10)\end{array}$ & $\begin{array}{c}-0.00327^{*} \\
(-1.99)\end{array}$ \\
\hline XIII lex & $\begin{array}{c}0.00444 \\
(0.37)\end{array}$ & $\begin{array}{c}0.00392 \\
(0.29)\end{array}$ & $\begin{array}{c}0.00686 \\
(0.49)\end{array}$ \\
\hline XIV lex & $\begin{array}{c}0.0285^{*} \\
(2.00)\end{array}$ & $\begin{array}{c}0.0221 \\
(1.59)\end{array}$ & $\begin{array}{c}0.0218 \\
(1.53)\end{array}$ \\
\hline female & $\begin{array}{c}-0.0291^{*} \\
(-2.17)\end{array}$ & $\begin{array}{c}-0.0348 \\
(-1.92)\end{array}$ & $\begin{array}{c}-0.0356 \\
(-1.82)\end{array}$ \\
\hline constant & $\begin{array}{c}0.0832 \\
(1.70) \\
\end{array}$ & & \\
\hline $\begin{array}{l}N \\
R^{2}\end{array}$ & $\begin{array}{l}1797 \\
0.079\end{array}$ & 1797 & 1797 \\
\hline pseudo $R^{2}$ & & 0.2035 & 0.2065 \\
\hline
\end{tabular}




\section{References}

Benedetta Bellò and Alessandro Spano. Governing the purple zone: How politicians influence public managers. European Management Journal, 2015.

Paolo Bellucci and Paolo Segatti. Votare in Italia. Società editrice il Mulino, 2010.

Nicole Bolleyer. Inside the cartel party: party organisation in government and opposition. Political Studies, 57(3):559-579, 2009.

Bernardo Bortolotti and Mara Faccio. Government control of privatized firms. Review of Financial Studies, 22(8):2907-2939, 2009.

Bernardo Bortolotti, Laura Pellizzola, and Carlo Scarpa. Majors as shareholders: an empirical analysis of municipal capitalism in italy. Mercato concorrenza regole, 9(3):535-568, 2007.

Narjess Boubakri, Jean-Claude Cosset, and Walid Saffar. Political connections of newly privatized firms. Journal of Corporate Finance, 14(5):654-673, 2008.

Shaun Bowler, David M Farrell, Richard S Katz, et al. Party discipline and parliamentary government. The Ohio State University Press, 1999.

Bruce Cain, John Ferejohn, and Morris Fiorina. The personal vote: Constituency service and electoral independence. Harvard University Press, 1987.

A. Colin Cameron and Pravin K. Trivedi. Microeconometrics: methods and applications. Cambridge university press, 2005.

Nadia Carboni. Changing relationships between politicians and bureaucrats in contemporary democracies: an empirical analysis of the italian experience. International Public Management Review, 11(1):90-109, 2010.

Nadia Carboni. Professional autonomy versus political control how to deal with the dilemma. some evidence from the italian core executive. Public Policy and Administration, 25(4):365-386, 2010.

Alessandro Carretta, Vincenzo Farina, Abhishek Gon, and Antonio Parisi. Politicians on board: do political connections affect banking activities in italy? European Management Review, 9(2):75-83, 2012.

Jamie L Carson, Gregory Koger, Matthew J Lebo, and Everett Young. The electoral costs of party loyalty in congress. American Journal of Political Science, 54(3):598-616, 2010.

Alberto Cavaliere. Privatizzazione e regolamentazione delle imprese pubbliche locali. Economia pubblica, 1997. 
Michael I Cragg and IJ Alexander Dyck. Privatization and management incentives: evidence from the united kingdom. Journal of Law, Economics, and Organization, 19(1):176-217, 2003.

Annarita Criscitiello and Stefano Fella. The new government and the spoils system. Italian Politics, 22:137-153, 2006.

Sergio De Nardis. Privatizzazioni, liberalizzazioni, sviluppo: introduzione e sintesi. in Le Privatizzazioni Italiane, pages 9-41, 2000.

Fabrizio Di Mascio. Come i partiti controllano lo stato: il patronage in europa. Rivista italiana di scienza politica, 41(2):291-314, 2011.

Fabrizio Di Mascio. Changing political parties, persistent patronage: The italian case in comparative perspective. Comparative European Politics, 10(4):377398,2012 .

Laurenz Ennser-Jedenastik. The politics of patronage and coalition: how parties allocate managerial positions in state-owned enterprises. Political Studies, 62(2):398-417, 2014.

Stefano Gagliarducci, Tommaso Nannicini, and Paolo Naticchioni. Moonlighting politicians. Journal of Public Economics, 94(9):688-699, 2010.

Vincenzo Galasso and Tommaso Nannicini. Competing on good politicians. American Political Science Review, 105(01):79-99, 2011.

Miriam A. Golden. Electoral connections: the effects of the personal vote on political patronage, bureaucracy and legislation in postwar italy. British Journal of Political Science, 33(02):189-212, 2003.

Bernard Grofman. Comparisons among electoral systems: Distinguishing between localism and candidate-centered politics. electoral Studies, 24(4):735$740,2005$.

William B Heller and Carol Mershon. Party switching in the italian chamber of deputies, 1996-2001. Journal of Politics, 67(2):536-559, 2005.

William B Heller and Carol Mershon. Dealing in discipline: party switching and legislative voting in the italian chamber of deputies, 1988-2000. American Journal of Political Science, 52(4):910-925, 2008.

William C Horrace and Ronald L Oaxaca. Results on the bias and inconsistency of ordinary least squares for the linear probability model. Economics Letters, 90(3):321-327, 2006.

Piero Ignazi and Eugenio Pizzimenti. The reins of intra-party power in the italian political parties (1990-2011). Rivista italiana di scienza politica, (3):223$245,2014$. 
Indridi $\mathrm{H}$ Indridason. To dissent or not to dissent: informative dissent and parliamentary governance. Economics of Governance, 9(4):363-392, 2008.

Christopher J Kam. Party discipline and parliamentary politics. Cambridge University Press, 2009.

Michael P. Keane and Antonio Merlo. Money, political ambition, and the career decisions of politicians. American Economic Journal: Microeconomics, $2(3): 186-215,2010$.

Petr Kopeckỳ, Peter Mair, and Maria Spirova. Party patronage and party government in European democracies. Oxford University Press, 2012.

Petr Kopeckỳ and Gerardo Scherlis. Party patronage in contemporary europe. European Review, 16(03):355-371, 2008.

Alfredo Macchiati. Breve storia delle privatizzazioni in italia: 1992-1999. ovvero: si poteva far meglio? Mercato concorrenza regole, 1(3):447-470, 1999.

Antonio Massarutto. La riforma dei servizi pubblici locali. liberalizzazione, privatizzazione o gattopardismo? Mercato concorrenza regole, 4(1):107-124, 2002.

Andrea Mattozzi and Antonio Merlo. Political careers or career politicians? Journal of Public Economics, 92(3):597-608, 2008.

Urtiaga María Gutiérrez Menozzi, Anna and Davide Vannoni. Board composition, political connections, and performance in state-owned enterprises. Industrial and Corporate Change, 21(3):671-698, 2012.

Paul Mitchell. Voters and their representatives: Electoral institutions and delegation in parliamentary democracies. European Journal of Political Research, 37(3):335-351, 2000.

Yair Mundlak. On the pooling of time series and cross section data. Econometrica, pages 69-85, 1978.

Edoardo Ongaro. The role of politics and institutions in the italian administrative reform trajectory. Public Administration, 89(3):738-755, 2011.

David EM Sappington and Joseph E Stiglitz. Privatization, information and david e-54-sflepinswn. Journal of Policy Analysis and Management, 6(4):567$582,1987$.

Andrei Shleifer and Robert W Vishny. Politicians and firms. The Quarterly Journal of Economics, pages 995-1025, 1994.

Ingrid Van Biezen and Petr Kopeckỳ. The cartel party and the state partystate linkages in european democracies. Party Politics, 20(2):170-182, 2014. 
Richard Van Weelden. Candidates, credibility, and re-election incentives. The Review of Economic Studies, 80(4):1622-1651, 2013.

Luca Verzichelli. La classe politica della transizione. Rivista italiana di scienza politica, 26(3):634-674, 1996.

Luca Verzichelli. The uncertain parliament: The instability of party groups in italy after 1994. Polichange, 2:4, 1999.

John Vickers and George Yarrow. Economic perspectives on privatization. The Journal of Economic Perspectives, pages 111-132, 1991.

Nick Vivyan and Markus Wagner. Do voters reward rebellion? the electoral accountability of mps in britain. European Journal of Political Research, 51(2):235-264, 2012.

Jeffrey M Wooldridge. Econometric Analysis of Cross Section and Panel Data. MIT Press, 2002.

Jeffrey M. Wooldridge. Econometric analysis of cross section and panel data. MIT press, 2010. 